\title{
ODNOS AFEKTIVNOG TEMPERAMENTA SA DIMENZIJAMA MENTALNOG ZDRAVLJA ${ }^{2}$
}

\begin{abstract}
Apstrakt
U radu je ispitan odnos afektivnih dimenzija temperamenta (depresivni, ciklotimni, hipertimni, iritabilni, anksiozno-kognitivni i anksiozno-somatski) i simptoma na četiri Terluinove dimenzije mentalnog zdravlja (Distres, Depresija, Anksioznost i Somatizacija). Na prigodnom uzorku od 190 osoba, mlađih od 35 godina, primenjena je srpska verzija skale TEMPS-a, koja meri stepen izraženosti osobina afektivnih temperamenata i Četvorodimenzionalni upitnik indikatora mentalnog zdravlja (4DSQ). Rezultati pokazuju da su depresivni i ciklotimni temperament značajni prediktori svih dimenzija simptoma. Pored njih, Anksioznost se značajno može predvideti na osnovu hipertimnog, anksiozno-kognitivnog i anksiozno-somatskog temperamenta, a Somatizacija na osnovu anksiozno-somatskog temperamenta. U svim regresionim modelima dimenzije afektivnog temperamenta ostvaruju pozitivan prediktorski doprinos, osim hipertimnog temperamenta koji jedino na dimenziji Anksioznost ima značajan negativni prediktorski doprinos. Osnovni zaključak istraživanja je da kod osoba sa depresivnim, anksioznim i somatskim karakteristikama temperamenta, u stresnim situacijama može doći do intenziviranja simptoma. Takođe, hipertimni temperament, koga odlikuje najveći broj poželjnih osobina, pokazuje potencijalno zaštitnu ulogu u odnosu na razvoj simptoma na Terluinovim dimenzijama.
\end{abstract}

Ključne reči: afektivni temperament, dimenzije mentalnog zdravlja, distres

\section{Uvod}

\section{Afektivni temperamenti}

Iako ne postoji konsenzus oko definicije temperamenta, pomenuti koncept se obično definiše tako da obuhvata karakteristične obrasce ponašanja i osećanja koji se oslanjaju na biološko nasleđe deteta i pojavljuju se rano u detinjstvu (Kagan, 2014). Ovi obrasci karakterišu osobu tokom većeg dela života. Sam pojam obično podrazumeva genetsko-biološke komponente ponašanja, koje se ispoljavaju kroz niz znakova i obeležja u koja spadaju određeno stabilno raspoloženje, odnos prema oko-

\footnotetext{
${ }^{1}$ dusan.vlajic@filfak.ni.ac.rs

${ }^{2}$ Rad je nastao u okviru projekta pod brojem: 183/1-16-9-01, a pod nazivom „Primenjena psihologija u funkciji kvaliteta života pojedinca u zajednici“, Departmana za psihologiju, Filozofskog fakulteta, Univerziteta u Nišu
} 
lini, osetljivost na spoljašnje stimuluse i karakterističan način reagovanja (Ratković, 2017).

Shvatanje da se ličnost čoveka može definisati kao svojevrsna "mešavina” tipova temperamenata, tačnije da se čovekove emotivne reakcije, doživljavanja i osećanja mogu povezati sa temperamentom, potiče još od Hipokrata i Aristotela (DembińskaKrajewska \& Rybakowski, 2014). Sledeća koncepcija temperamenta značajna za današnje shvatanje vodi poreklo iz grčke i rimske medicine, koje pretpostavljaju da je temperament konstitucionalni obrazac emocionalne reaktivnosti (Akiskal \& Akiskal, 2007). Nastavak ove tradicije predstavlja Krepelinovo učenje, ovaj autor je formirao teoriju o četiri tipa temperamenta (depresivni, manični, ciklotimni i iritabilni), a koji su konceptualizovani kao subkliničke forme afektivnih poremećaja. Pomenuti koncept temperamenta je prihvatio i dalje razvio Hagop Akiskal (Dembińska-Krajewska \& Rybakowski, 2014). Pomenuti autor navodi da postoji pet dimenzija afektivnih temperamenata - depresivni, hipertimni, ciklotimni, iritabilni i anksiozni.

Depresivni temperament odlikuje osobe koje su sklone rutini i samookrivljavanju, zavisne su, stidljive, sklone da budu podređene, osetljive na kritiku, ali i sklone samoodricanju, osetljive za patnju drugih, pouzdane i uporne (Akiskal \& Akiskal, 2007). Generalno, karakteriše ih manjak energije, pa ih to onemogućava da učestvuju u zadacima koji zahtevaju visok nivo aktiviteta (Dembińska-Krajewska \& Rybakowski, 2014). Istraživanje sprovedeno u Italiji (Signoretta, Maremmani, Liguori, Perugi, \& Akiskal, 2005), u kome su afektivni temperamenti kod studenata i mladih odraslih osoba procenjivani putem TEMPS-I, odnosno italijanske verzije polustrukturisanog intervjua koji procenjuje crte temperamenata iz Akiskalovog modela (Temperament Evaluation of Memphis, Pisa, Paris and San Diego - Interview version), pokazalo je da depresivni temperament karakteriše socijalna inhibicija i manjak, kako antisocijalnog, tako i hiperaktivnog ponašanja (okrutnost prema životinjama, grickanje noktiju, piromanija; Signoretta et al., 2005), što govori u prilog tome da se depresivni temperament delimično poklapa sa inhibicijom u ponašanju, za koju se pokazalo da je faktor rizika u razvoju socijalne anksioznosti (Biederman et al., 1990). Takođe, depresivni temperament je povezan sa sklonošću ka brizi, problemima sa koncentracijom (Walsh, Brown, Barrantes-Vidal, \& Kwapil, 2013), smanjenom sposobnošću interakcije sa drugima i problemima u interpersonalnim relacijama (Rovai et al., 2013a).

Hipertimni temperament se odlikuje najvećim brojem adaptivnih osobina: optimistični su, zabavni, društveni, skloni šalama, samouvereni, puni ideja, elokventni, stalno u pokretu. Oni manje spavaju, ne umaraju se lako, vole da preuzmu vodeću ulogu i pokazuju najveći intenzitet emocionalnih reakcija (Dembińska-Krajewska \& Rybakowski, 2014). Neadaptivne osobine ovog temperamenta su da jednostrano gledaju na problem, skloni su preuzimanju rizika i ne prihvataju kritike na račun svoje nametljivosti i karaktera (Akiskal \& Akiskal, 2007; Dembińska-Krajewska \& Rybakowski, 2014). Hipertimni temperament je pozitivno povezan sa doživljajem prijatnih emocija, visokom energičnošću, bezbrižnošću, društvenošću, pozitivnom percepcijom svakodnevnog života, ali i grandioznom percepcijom sebe (Walsch et al., 2013), kao i sa visokim nivoom emocionalnosti (Rovai et al., 2013a). Istraživa- 
nje povezanosti temperamenta i dijagnostičkih kategorija prema DSM-IV klasifikaciji je pokazalo da hipertimni temperament ima "zaštitnu" ulogu u pogledu brojnih mentalnih poremećaja, ali ne i prema bipolarnom poremećaju i teškoći u kontroli impulsa (Karam et al., 2010). Hipertimni temperament pozitivno korelira sa Klonindžerovom dimenzijom Potraga za novinama (Ristić-Ignjatović et al., 2014), koja se definiše kao tendencija ka iniciranju i aktivaciji ponašanja i obuhvata osobine kao što su radoznalost, impulsivnost, entuzijazam, sklonost ekstravagantnom ponašanju i neurednost. Hipertimni temperament negativno korelira sa drugom Klonindžerovom dimenzijom - Izbegavanje štete (Ristić-Ignjatović et al., 2014), koja je definisana kao dispozicija za inhibiciju ili prekid ponašanja i korespondira sa emocijom straha (Džamonja-Ignjatović i Milanović, 2012). Hipertimne osobe uglavnom nisu sklone doživljavanju simptoma anksioznosti i depresivnosti (Lazary, Gonda, Benko, Gacser, \& Bagdy, 2009; Morvan et al., 2011).

Ciklotimni temperament je nestabilnog raspoloženja, promenljive energije i samopouzdanja i nestabilan u socijalnim odnosima. Ove osobe su sklone površnom razmišljanju, ali su spremne da ulažu intelektualni napor kako bi razumele situaciju. Doživljavaju intenzivna osećanja, sklone su emocionalnim izlivima i spremne da brzo uđu u nove odnose. Adaptivna osobina je visok nivo kreativnosti (DembińskaKrajewska \& Rybakowski, 2014). Istraživanja su pokazala da su ljudi ciklotimnog, ali i depresivnog temperamenta manifestovali povišenu reaktivnost na stres (Walsh et al., 2013). Ciklotimni temperament pokazuje najveći broj emocionalnih i bihejvioralnih problema, a značajno je povezan sa poremećajima sna izazvanih anksioznošću, separacionom anksioznošću, poremećajima ishrane kod žena i antisocijalnim i agresivnim ponašanjem kod muškaraca (Signoretta et al., 2005).

Iritabilni temperament je skeptičan i kritičan, što mogu biti poželjne intelektualne osobine. Sa druge strane, ima "najmračniju" prirodu od svih, jer se ove osobe često žale i mrzovoljne su, nezadovoljne, sklone besu, nasilju i seksualnoj ljubomori (Akiskal \& Akiskal, 2007). Ovaj temperament karakteriše redukovana želja za socijalnim kontaktima i bliskošću (Walsh et al., 2013). Iritabilni temperament se delimično poklapa sa ciklotimnim, ali se od njega razlikuje po tome što ima viši nivo energije i niži nivo empatije (Dembińska-Krajewska \& Rybakowski, 2014).

Osobe sa anksioznim temperamentom su sklone brizi i ruminiranju, a doživljavaju konstantnu fizičku i psihičku tenziju koja može dovesti do somatskih simptoma (Dembińska-Krajewska \& Rybakowski, 2014). Istraživanje Karama i saradnika (Karam et al., 2010) pokazalo je da je anksiozni temperament snažan prediktor anksioznih i depresivnih poremećaja. Iz prethodnih opisa se može zaključiti da svi temperamenti imaju i pozitivne i negativne karakteristike, pa samim tim mogu imati bilo povoljan, bilo nepovoljan efekat na kvalitet života i socijalne interakcije.

Istraživanja su pokazala da su afektivni temperamenti stabilni tokom vremena (Kawamura et al., 2010) i da imaju i univerzalne i kulturalno-specifične karakteristike (Vázquez, Tondo, Mazzarini, \& Gonda, 2012). Afektivni temperamenti leže u osnovi stabilnih obrazaca ponašanja i crta ličnosti (Rovai et al., 2013b), ali isto tako mogu da imaju i ključnu ulogu za razvoj afektivnih poremećaja i bolesti zavisnosti, naročito kada su preterano intenzivni (Ratković, 2017). Istraživanje sprovedeno kod 
nas (Ristić-Ignjatović et al., 2014) pokazalo je da su osobe sa depresivnim, anksioznim i ciklotimnim temperamentom sklone negativnim doživljavanjima, poput zabrinutosti, pesimizma, neodlučnosti i nesigurnosti, povučenosti, stidljivosti i umora (Džamonja-Ignjatović i Milanović, 2012).

\section{Indikatori mentalnog zdravlja}

Terluin je sa saradnicima (Terluin et al., 2004) ispitivao prevalenciju distresa u opštoj populaciji. Pod distresom je podrazumevao skup simptoma, koji nastaje prilikom suočavanja sa stresorima, i koji nema toliki intenzitet da zadovolji kriterijume za dijagnozu poremećaja raspoloženja, pre svega anksioznih i depresivnih. Njihovo ispitivanje pacijenata koji dolaze u ustanove primarne zdravstvene zaštite je dovelo do identifikovanja 4 simptomatske dimenzije: Distres, Depresija, Anksioznost i Somatizacija, koje obuhvataju čitav spektar žalbi na psihičke simptome. Dimezija Distresa se odnosi na simptome koji nastaju kao rezultat susretanja sa stresorom, kao i napora koji osoba ulaže da bi se izborila sa uzrokom problema i održala adekvatan nivo psihosocijalnog funkcionisanja (Terluin et al., 2004). Obuhvata zabrinutost, razdražljivost, napetost, malaksalost, slabu koncentraciju, probleme sa spavanjem i demoralizaciju (Terluin et al., 2006). Dimenzija Depresije se odnosi na depresivne misli, uključujući i suicidalne ideje i gubitak zadovoljstva (anhedoniju), tj. simptome koji karakterišu klinički oblik depresije. Anksioznost obuhvata simptome kao što su slobodno-lebdeća anksioznost, panični napadi i izbegavajuće ponašanje tj. simptomi koji karakterišu anksiozni poremećaj. Somatizacija se odnosi na psihosomatske reakcije, tj. na telesne simptome kada su malobrojni i blagi. U slučajevima kada su simptomi intenzivniji i mnogobrojni dimenzija obuhvata psihijatrijske poremećaje, npr. hipohondriju ili somatizacioni poremećaj (Terluin et al., 2004). Sadržaj ove dimenzije obuhvata i tendenciju da se iskustvo neobjašnjenih telesnih simptoma pripiše telesnoj bolesti (Terluin et al., 2006). Različiti mehanizmi mogu da doprinesu ovakvom načinu reagovanja (senzitivisanost mozga na telesne senzacije, poremećaji nervnog i endokrinog sistema, povećana svesnost o telesnim senzacijama, nefunkcionalna uverenja o telesnim bolestima i poremećajima). Doživljaj nekolicine neprijatnih telesnih senzacija je karakteristika većine ljudi kada se nađu u stresnim situacijama. Međutim, ukoliko osoba doživi veliki broj ,neobjašnjivih" simptoma iz različitih sistema organa (vrtoglavica, bol u stomaku, palpitacije, mišićni bolovi), verovatno je reč o somatizaciji.

Dimenzija Distresa odnosi se na simptome koje doživljava velika većina ljudi kada su ,pod stresom“, dok se ostale dimenzije odnose na kliničke oblike mentalnih poremećaja (Terluin et al., 2004). Autori postuliraju odnos dimenzija na sledeći način. Delovanje stresora, tačnije događaja koji ugrožavaju uobičajeno funkcionisanje i dobrobit osobe, dovodi do različitih simptoma (umor, loša koncentracija, emocionalno iscrpljivanje, potreba za odmorom, doživljaj blagih telesnih simptoma, povišen krvni pritisak, izmenjene imunološke reakcije, palpitacije, povišen mišićni tonus, mijalgija), pri čemu neki od njih ostanu neopaženi tokom dužeg vremenskog perioda. Sa druge strane, neki od pobrojanih simptoma se lakše opažaju, a termin distres se odnosi upravo na ovakve simptome. Ti simptomi motivišu čoveka da pokrene 
različite strategije prevladavanja (koping-mehanizme) da bi se sa njima izborio i time smanjio uticaj stresora. Neki ljudi koriste uspešne strategije prevladavanja koje umanjuju dejstvo distresa, a drugi koriste manje adekvatne strategije, koje povećavaju distres. Međutim, kod osoba kod kojih su prisutni izvesni faktori rizika, distres izaziva psihičke smetnje i poremećaje, koje Terluin opisuje uz pomoć simptoma na preostale tri dimenzije. Te smetnje mogu da deluju povratno kao stresor, time izazivajući dodatni distres i pojačavanje simptoma. Upravo zbog ovakvog odnosa Distresa i ostalih dimenzija, Terluin (2004) smatra da osobe sa poremećajima raspoloženja pokazuju kombinaciju simptoma distresa i depresije, tj. distresa i anksioznosti, koji su, u manjoj ili većoj meri, udruženi sa simptomima somatizacije.

\section{Problem istraživanja}

Osnovni problem ovog istraživanja je ispitivanje predikcije Terluinovih dimenzija mentalnog zdravlja na osnovu dimenzija afektivnih temperamenata. Terluinov model je razvijen u okviru ispitivanja prevalence doživljavanja simptoma distresa prilikom suočavanja sa stresorima. Sa druge strane, temperament, kao biološka osnova na kojoj se gradi ličnost, čini pojedince u različitoj meri osetljivim za stresore iz spoljašnjeg okruženja. Preciznije govoreći, temperament utiče na doživljaj stresa i na njegove posledice, time što određuje način na koji ljudi percipiraju i reaguju na stresore i način kako se bore sa stresnom situacijom (Strelau \& Zawadzki, 2011). Dalje, rezultati prethodnih istraživanja pokazuju da temperament može biti povezan sa depresivnim tendencijama, ali i klinički dijagnostikovanom depresijom (Clark, Watson, \& Mineka, 1994; Watson \& Clark, 1995). Takođe, klaster dimenzija temperamenta, koji se manifestuje kroz nisku upornost i koncentraciju, negativnu emocionalnost i nisku društvenost, povezan je sa depresivnim tendencijama (Windle, 1991; Tubman \& Windle, 1995). Visoka negativna emocionalnost povezana je sa kliničkom depresijom i depresivnim tendencijama (Goodyear, Ashby, Altham, Vize, \& Cooper, 1993; Rende, 1993; Watson \& Clark, 1984; 1995), a isto tako i sa anksioznošću (Clark \& Watson, 1991a; 1991b; Clark et al., 1994). Visok nivo neuroticizma, koji je blizak negativnoj emocionalnosti, povezan je sa lošim ukupnim oporavkom i hroničnošću depresivnih poremećaja (Andress, Neilson, Hunt, Stewart, \& Kiloh, 1990), dodatno podvlačeći klinički značaj doživljavanja negativnih emocija. Iako su navedena istraživanja ispitivala drugačije modele temperamenta, između njih i Akiskalovih temperamenata se može povući paralela u smislu negativne emocionalnosti koja je zajednička karakteristika svih afektivnih temperamenata, osim hipertimnog. Zbog toga se može očekivati da će osobe sa karakteristikama Akiskalovih afektivnih temperamenta biti sklone negativnim emocijama, koje dalje mogu uzrokovati probleme u psihosocijalnom funkcionisanju.

$\mathrm{U}$ prethodnom istraživanju su afektivni temperamenti ispitivani u kontekstu reagovanja na stresne situacije (Walsh et al., 2013), konkretno, moderatorski efekat temperamenta u odnosu efekata konteksta svakodnevnog života na pojavu različitih rizičnih ponašanja. Takođe, ispitivan je i prediktorski doprinos afektivnih temperamenata u objašnjenju depresivnih simptoma pri čemu je pokazano da se ovaj odnos 
menja u zavisnosti od broja i intenziteta stresnih životnih događaja (Gonda et al., 2020). Međutim, prema dosadašnjem saznanju autora, nema istraživanja u kojem je ispitivano da li karakteristike temperamenata imaju doprinos u predikciji simptoma preostalih Terluinovih dimenzija. Osnovna pretpostavka ovog istraživanja je da će temperamenti biti značajni prediktori svih simptoma Terluinovih dimenzija s obzirom na teorijsko preklapanje konstrukata i to da stresna situacija potencira neke od simptoma (Terluin et al., 2004), a koji su slični karakteristikama afektivnih temperamenata. Pretpostavka je da će hipertimni temperament imati negativan doprinos predikciji simptoma, čime bi se potvrdila njegova zaštitna uloga (Karam et al., 2010; Gonda et al., 2020), dok bi ostali temperamenti ostvarili pozitivan doprinos.

\section{Metod}

\section{Uzorak i procedura}

Uzorak je prigodan i čini ga 190 osoba (94 osoba muškog i 96 ženskog pola), mlađih od 35 godina, različitog stepena obrazovanja. Starost ispitanika se kreće u rasponu od 18 do 35 godina $(A S=25.00, S D=4.54)$. Podaci su prikupljani onlajn, a upitnici su distibuirani putem društvenih mreža. Pre popunjavanja upitnika ispitanici su bili obavešteni da je ispitivanje anonimno i da će odgovori biti korišćeni isključivo u naučno-istraživačke svrhe.

\section{Instrumenti istraživanja}

Skala procene afektivnih temperamenata (Temperament Evaluation of Memphis, Pisa, Paris and San Diego-autoquestionnaire: TEMPS-A; Akiskal, Akiskal, Haykal, Manning, \& Connor, 2005a, Akiskal et al., 2005b). Ovaj upitnik za procenu dimenzija afektivnih temperamenata validiran je na domaćoj nekliničkoj populaciji (Ristić-Ignjatović et al., 2014). Upitnik se sastoji od 41 ajtema binarnog formata odgovora (tačno/netačno). Ajtemi su grupisani u 6 dimenzija: depresivni, ciklotimni, hipertimni, iritabilni, anksiozno-kognitivni ili anksiozno-somatski temperament. Autori domaće validacione studije (Ristić-Ignjatović et al., 2014) razdvojili su jedinstveni faktor anksioznosti na: 1) anksiozno-kognitivni, koji se odnosi na sklonost ka brizi i dobrim delom se poklapa sa depresivnošću, i 2) anksiozno-somatski, koji se odnosi na somatske korelate anksioznosti i obuhvata stresom izazvane simptome poput: glavobolje, podrhtavanja ruku, neprijatnog osećaja u stomaku, mučnine, dijareje, učestalih odlazaka u toalet itd. U ovom istraživanju alfa koeficijent pouzdanosti $(\alpha)$ dimenzija iznosi: .75 za depresivni temperament (7 ajtema), .82 za ciklotimni ( 7 ajtema), .69 za hipertimni ( 7 ajtema), .69 za iritabilni ( 8 ajtema), .78 za anksiozno-kognitivni (6 ajtema) i .66 za anksiozno-somatski (6 ajtema).

Četvorodimenzionalni upitnik indikatora mentalnog zdravlja (The FourDimensional Symptom Questionnaire: 4DSQ; Terluin et al., 2004). Upitnik obuhvata simptome na 4 dimenzije: Distres $(\alpha=.92)$, Depresija $(\alpha=.89)$, Anskioznost $(\alpha=.87)$ i Somatizacija $(\alpha=.84)$. Dimenzije Distresa i Somatizacije obuhvataju po 
16 ajtema, subskala Anksioznosti 12, a Depresije 6 ajtema. Format odgovaranja je Likertova petostepena skala (od $0=$ nikada do $4=$ veoma često/konstantno). Sadržaj stavki se odnosi na tipične simptome koje ljudi doživljavaju u susretu sa stresorom, a ispitanici izražavaju učestalost doživljavanja simptoma u poslednjih sedam dana. U ovom istraživanju je korišćeno originalno skorovanje (Terluin et al., 2004), po kom se petostepena skala skoruje kao trostepena $(0=$ nikada, $1=$ ponekad, $2=s$ vremena na vreme, često $i$ veoma često/konstantno). Pouzdanosti u ovom istraživanju su u skladu sa prethodnim istraživanjima (Jelić, Popov i Sretković, 2014; Terluin et al., 2004).

\section{Rezultati}

Deskriptivno-statistički pokazatelji varijabli se mogu videti u Tabeli 1. S obzirom na to da su vrednosti skjunisa i kurtozisa u opsegu od -2 do +2 , može se smatrati da su distribucije svih varijabli u granicama prihvatljivosti za normalnu distribuciju.

Tabela 1

Deskriptivni pokazatelji varijabli

\begin{tabular}{lcccccc}
\hline Varijable & Min. & Maks. & $A S$ & $S D$ & \multicolumn{1}{c}{$S k$} & $K u$ \\
\hline Depresivni & 0 & 1 & 0.23 & 0.26 & 0.92 & -0.26 \\
Ciklotimni & 0 & 1 & 0.39 & 0.34 & 0.48 & -1.08 \\
Hipertimni & 0 & 1 & 0.63 & 0.28 & -0.46 & -0.69 \\
Iritabilni & 0 & 1 & 0.30 & 0.24 & 0.82 & 0.33 \\
Anksiozno-kognitivni & 0 & 1 & 0.45 & 0.33 & 0.21 & -1.20 \\
Anksiozno-somatski & 0 & 1 & 0.38 & 0.29 & 0.31 & -0.91 \\
Distres & 0 & 32 & 15.95 & 9.47 & 0.12 & -1.11 \\
Depresija & 0 & 12 & 3.25 & 3.88 & 1.03 & -0.17 \\
Anksioznost & 0 & 22 & 4.73 & 5.28 & 1.29 & 0.90 \\
Somatizacija & 0 & 30 & 12.13 & 7.08 & 0.47 & -0.40 \\
\hline
\end{tabular}

Napomena. Minimalne i maksimalne vrednosti na TEMPS-A se odnose na uprosečene skorove (kreću se u rasponu od 0 do 1), a na 4DSQ na sumacione.

Da bi se došlo do podatka o zastupljenosti afektivnih temperamenata u uzorku, najpre su sumacioni skorovi prevedeni u standardizovane $z$-skorove. Kao granični skor određena je vrednost od $+2 S D$, što je u skladu sa ranijim istraživanjima (Figueira et al., 2010; Rózsa et al., 2013; Ristić-Ignjatović et al., 2014). Zastupljenost temperamenata je prikazana u Tabeli 2 , koja pokazuje da $90 \%$ ispitanika u uzorku nema jasno izražene dominatne karakteristike jednog od njih. Od preostalih ispitanika najzastupljeniji su oni sa dominantno iritabilnim, potom anksiozno-somatskim i depresivnim temperamentom. Najmanje je osoba kod kojih je dominantno izražena kombinacija karakteristika depresivnog i iritabilnog temperamenta. 
Tabela 2

Zastupljenost dominatnih afektivnih temperamenata bazirana na z-skorovima $(A S+2 S D)$

\begin{tabular}{lcc}
\hline & Broj ispitanika & Procenat \\
\hline Bez dominatnog temperamenta $(<2 S D)$ & 171 & $90 \%$ \\
1 dominantni temperament $(>2 S D)$ & 17 & $9 \%$ \\
2 dominantna temperamenta $(>2 S D)$ & 2 & $1 \%$ \\
\hline Depresivni & 3 & $1.6 \%$ \\
Iritabilni & 7 & $3.7 \%$ \\
Anksiozno-somatski & 7 & $3.7 \%$ \\
Depresivni i Iritabilni & 2 & $1 \%$ \\
\hline
\end{tabular}

U Tabeli 3 se vidi da jedino hipertimni temperament ostvaruje negativnu korelaciju umerenog intenziteta sa simptomatskim dimenzijama. Korelacija svih ostalih temperamenata i pomenutih dimenzija je pozitivna i umerenog je intenziteta. Sa dimenzijom Somatizacije hipertimni i iritabilni temperament ne ostvaruju statistički značajnu korelaciju.

Tabela 3

Pirsonovi koeficijenti korelacija između afektivnih temperamenata i Terluinovih dimenzija

\begin{tabular}{llllccc}
\hline & Dep. & Cik. & Hip. & Irit. & An.-kog. & An.-som. \\
\hline Distres & $.62^{* *}$ & $.60^{* *}$ & $-.33^{* *}$ & $.22^{* *}$ & $.42^{* *}$ & $.29^{* *}$ \\
Depresija & $.63^{* *}$ & $.54 * *$ & $-.30^{* *}$ & $.19^{* *}$ & $.33^{* *}$ & $.15^{*}$ \\
Anskioznost & $.56^{* *}$ & $.48^{* *}$ & $-.35^{* *}$ & $.19^{*}$ & $.48^{* *}$ & $.34^{* *}$ \\
Somatizacija & $.36^{* *}$ & $.37 * *$ & -.13 & .01 & $.30^{* *}$ & $.35^{* *}$ \\
\hline
\end{tabular}

Napomena . Dep. = depresivni; Cik. = ciklotimni; Hip. = hipertimni; Irit. = iritabilni; An.-kog. = anskiozno-kognitivni; An.-som. = Anksiozno-somatski. $* p<.05 ; * * p<.01$.

U Tabeli 4 se može videti da je predikcija simptoma značajna, te da se kreće u rasponu od 25\% (za Somatizaciju) do 50\% (za Distres). Vrednosti $\beta$ ukazuju na to da su depresivni i ciklotimni temperament značajni prediktori svih dimenzija simptoma, a u slučaju Anksioznosti značajnu predikciju ostvaruju i hipertimni temperament u negativnom i anksiozno-kognitivni i anksiozno-somatski u pozitivnom smeru. Anksiozno-somatski temperament ostvaruje značajnu pozitivnu predikciju i u slučaju Somatizacije.

Tabela 4

Predikcija skala simptoma na osnovu afektivnih temperamenata

\begin{tabular}{lcccccccc}
\hline & Distres & \multicolumn{3}{c}{ Depresija } & \multicolumn{3}{c}{ Anksioznost } & \multicolumn{3}{c}{ Somatizacija } \\
\cline { 2 - 9 } & $\beta$ & $p$ & $\beta$ & $P$ & $\beta$ & $p$ & $\beta$ & $p$ \\
\hline Depresivni & .32 & .000 & .47 & .000 & .27 & .000 & .21 & .013 \\
Ciklotimni & .33 & .000 & .29 & .000 & .15 & .037 & .22 & .008 \\
Hipertimni & -.10 & .074 & -.09 & .136 & -.15 & .016 & .07 & .303 \\
Iritabilni & .04 & .459 & -.01 & .853 & .06 & .309 & -.12 & .079 \\
Anksiozni- & .07 & .250 & -.03 & .683 & .22 & .001 & .06 & .413 \\
kognitivni & & & & & & & &
\end{tabular}


Odnos afektivnog temperamenta sa dimenzijama mentalnog zdravlja

$\begin{array}{lcccccccc}\text { Anksiozno- } & .10 & .080 & -.04 & .440 & .16 & .008 & .25 & .000 \\ \text { somatski } & .50 & .000 & .46 & .000 & .44 & .000 & .25 & .000 \\ R^{2} & .8 & \end{array}$

Napomena. $\beta=$ standardizovani regresioni koeficijenti.

\section{Diskusija}

Osnovni cilj ovog istraživanja je bio ispitati prediktivni doprinos dimenzija afektivnih temperamenata simptomima na Terluinovim dimenzijama mentalnog zdravlja (Distres, Depresija, Anksioznost i Somatizacija). Najpre je bila ispitana zastupljenost afektivnih temperamenata. Rezultati ukazuju na to da je hipertimni afektivni temperament najzastupljeniji, dok je najmanje zastupljen depresivni, što se u potpunosti poklapa sa rezultatima domaćih validacionih studija (Hinić, Akiskal, Akiskal, Jović, \& Ristić, 2013; Ristić-Ignjatović et al., 2014). Zastupljenost afektivnih temperamenata je takva da $90 \%$ ispitanika nema jasno definisane karakteristike jednog od njih, dok se kod preostalih 10\% sreću dominantni temperamenti. Rezultat se može objasniti time da su ispitanici iz nekliničke populacije, a da se afektivni temperamenti tretiraju kao subklinička forma afektivnih poremećaja (DembińskaKrajewska \& Rybakowski, 2014), čija se velika zastupljenost ne očekuje u opštoj populaciji mladih ljudi. Proporcija ispitanika u ovom istraživanju kod kojih se jasno ispoljavaju crte jednog ili više temperamenata su slične proporcijama ranijih istraživanja (Figueira et al., 2010; Rózsa et al., 2008), a osnovna razlika je u tome što u ovom uzorku nema ispitanika kod kojih su ciklotimni, hipertimni i anksiozno-kognitivni temperamenti dominantno izraženi. Ovakav nalaz može biti posledica oko pet puta manjeg uzorka ovog u poređenju sa uzorcima pomenutih istraživanja.

Dimenzije temperamenata i mentalnog zdravlja međusobno nisko do umereno koreliraju. Hipertimni temperament je negativno koreliran sa dimenzijama Distresa, Depresije i Anksioznosti, što može ukazivati na njegovu „najpozitivniju“ prirodu (Dembińska-Krajewska \& Rybakowski, 2014) i “zaštitnu” ulogu u pogledu različitih mentalnih poremećaja (Karam et al., 2010). Zaštitna uloga hipertimnog temperamenta je dokumentovana u prethodnim istraživanjima, a rezultati ovog istraživanja ukazuju na to da se zaštitna uloga može prepoznati i prilikom susretanja sa svakodnevnim stresorima, i potencijalno ukazuje na to da će optimistične, samouverene i društvene osobe lakše izaći na kraj sa stresorom, što bi ujedno značilo i manje zabrinutosti, razdražljivosti i napetosti.

Rezultati pokazuju da su depresivni i ciklotimni afektivni temperament prediktori Distresa i da ostvaruju pozitivnu korelaciju sa kriterijumskom varijablom, pri čemu ciklotimni temperament ima nešto viši parcijalni doprinos. Osobe ciklotimnog temperamenta ispoljavaju niz negativnih emocija u svakodnevnom životu, u koje spadaju i razdražljivost i zabrinutost, a ujedno doživljavaju svoje okruženje kao stresnije (Walsch et al., 2013). Sa druge strane, dimenzija Distresa obuhvata simptome koji nastaju kao rezultat susretanja sa stresorom (Terluin et al., 2004), a to su upravo razdražljivost i napetost (Terluin et al., 2006). Nalaz ovog istraživanja pokazuje 
da nestabilnost ciklotimnog temperamenta može dovesti do opažanja neposrednog okruženja zahtevnijim nego što jeste što može dodatno pojačavati simptome i time potencijalno dalje kompromitovati kapacitete osobe da se uspešno adaptira na zahteve situacije. Osobe sa dominantno depresivnim temperamentom su često pesimistične, smatraju da se stvari odvijaju loše i da doživljavaju samo neuspehe. Ovakav negativističan stav može dovesti do tumačenja spoljašnjih događaja kao prezahtevnih, što bi dalje dovelo do snažnijeg razvijanja simptoma Distresa. Ovome u prilog ide i činjenica da su osobe sa depresivnim temperamentom sklone krutom razmišljanju (Ratković, 2017), što je povezano sa nemogućnošću da lako izađu na kraj sa zahtevima spoljašnje sredine. Slična objašnjenja važe i za regresioni model, u kome je kriterijumska varijabla dimenzija Depresije, a čiji su prediktori, takođe, ciklotimni i depresivni temperament. S obzirom na to da se depresivni temperament karakteriše anhedonijom, letargijom i dubokim doživljajem tuge (Walsch et al., 2013), a da ajtemi koji mere simptome dimenzije Depresije obuhvataju doživljaje osobe da ne vidi izlaz iz situacije, da život nema smisla i da nema sposobnost da više uživa u bilo čemu, može se zaključiti da je preklapanje koncepata veliko i da će temperamentalna dispozicija ka depresivnom doživljavanju dodatno biti potencirana stresorima. Sa druge strane, osnovna karakteristika ciklotimnog temperamenta su oscilacije između depresivnosti i hipomanije (Walsch, Royal, Barrantes-Vidal, \& Kwapil, 2012). To delimično preklapanje depresivnog i ciklotimnog temperamenta objašnjava zbog čega se oba izdvajaju kao statistički značajni prediktori Depresije. Rezultat ovog istraživanja je u skladu sa rezultatima ranijih koja pokazuju da ciklotimni i depresivni objašnjavaju deo varijanse skorova na skalama depresivnosti (Lazary et al., 2009).

Dimenziju Anksioznosti objašnjava najveći broj prediktora. Jedino hipertimni temperament ima negativnu korelaciju, dok depresivni, ciklotimni, anksiozno-kognitivni i anksiozno-somatski ostvaruju pozitivnu korelaciju sa kriterijumskom varijablom. Objašnjenje rezultata se može naći u sklonosti depresivnim doživljavanjima kako depresivnog tako i ciklotimnog temperamenta. Dalje, u praksi se depresivnost često javlja udružena sa simptomima anksioznosti (Marić, 2005). Stoga na čudi što bi kod osoba koje imaju trajnu dispoziciju ka depresivnosti i anskioznosti u stresnim situacijama takva doživljavanja mogla biti dodatno potencirana, čak do te mere da mogu poprimiti oblik anksioznih poremećaja (Terluin et al., 2004). Sa druge strane, korelacija osobina hipertimnog temperamenta sa kriterijumom je negativna, što je posledica sklonosti hipertimnih osoba ka doživljavanju prijatnih emocija i njihove pozitivne percepcije svakodnevnog života (Walsch et al., 2013). Takva percepcija potencijalno štiti od štetnog delovanja stresora, jer ih osoba ne doživljava kao ugrožavajuće. Time se prevenira i razvoj simptoma dimenzije Distresa, koji, ako je osoba vulnerabilna, mogu da se udruže sa simptomima na dimenziji Anksioznosti (Terluin et al., 2004). Razmatrani rezultat istraživanja je još jedna potvrda svojevrsne "zaštitne" uloge hipertimnog temperamenta (Karam et al., 2010), a u skladu je i sa istraživanjima koja pokazuju da osobe hipertimnog temperamenta uglavnom nisu sklone doživljavanju simptoma anksioznosti (Lazary et al., 2009; Morvan et al., 2011).

U poslednjem regresionom modelu se kao statistički značajni prediktori Somatizacije izdvajaju depresivni, ciklotimni i anksiozno-somatski temperament. Objaš- 
njenje ovih rezultata se može naći u činjenici da dimenziju Somatizacije karakterišu žalbe na brojne telesne simptome, (Terluin et al., 2004) koji se takođe mogu javiti u sklopu karakteristika ovih temperamenata, ali i kao telesne manifestacije anksioznosti i depresivnosti (Marić, 2005). Ovo istraživanje pokazuje da anksiozno-depresivna doživljavanja mogu da ukazuju na sklonost ka razvoju somatskih simptoma. Rezultat je u skladu sa nalazima domaće validacione studije u kojoj je izdvojen anksiozno-somatski afektivni temperament, a koji obuhvata somatska ispoljavanja anksioznosti (Ristić-Ignjatović et al., 2014), čime se dodatno potvrđuje pomenuta sklonost.

Iritabilni temperament se nije pokazao kao statistički značajan prediktor Terluinovih dimenzija. On se smatra podtipom ciklotimnog temperamenta, a neki autori ih grupišu i tretiraju kao jednu varijablu u istraživanjima (Walsch et al., 2012; Walsch et al., 2013). U literaturi se sreće tumačenje da je iritabilni temperament mešavina karakteristika depresivnog, ciklotimnog i hipertimnog temperamenta, koji leže u njegovoj osnovi. Ovo tumačenje potiče još od Krepelina, prisutno je i danas (Maremmani et al., 2011). Verovatno da odsustvo statistički značajnog doprinosa ovog temperamenta potiče od njegove nedovoljno jasne i precizne konceptualizacije, te samim tim i diferencijacije u odnosu na ostale tipove temperamenta.

$\mathrm{Na}$ kraju treba reći da je istraživanje obuhvatilo osobe do 35 godina starosti, uglavnom studente. Bilo bi korisno da dalja istraživanja obuhvate starije ispitanike sa ciljem provere nalaza ovog istraživanja, koje pokazuje polarizaciju, sa jedne strane, pozitivnih osobina hipertimnog temperamenta poput optimizma, društvenosti i samopouzdanja i, sa druge strane, tendencije ostalih temperamenata ka razvijanju brojnih simptoma pri suočavaju sa stresorom. S obzirom na to da su prethodne studije pretežno transverzalne, da su u njima učestvovali mlađi ispitanici (Preti et al., 2013, Vazquez et al., 2012), da nisu pružile jednoznačne rezultate u pogledu stabilnosti afektivnih temperamenata tokom godina, kao i da, prema saznanju autora ovog istraživanja, nisu objavljena istraživanja koja su povezivala afektivne temperamente i dimenzije Terluinovog modela, teško je predvideti potencijalne rezultate studija sa starijim ispitanicima. Dalje, ovo istraživanje nije uzelo u obzir razlike u odnosu na pol, koje mogu biti od značaja, jer je zastupljenost afektivnih temperamenata različita kod različitih polova (Hinić i sar., 2013; Vazquez et al., 2012), što bi moglo da se odrazi i na prediktivne modele. Takođe, buduća istraživanja bi mogla direktno ispitivati potencijalne efekte koje bi strategije prevladavanja stresa mogle imati na varijable ovog istraživanja, s obzirom na to da se simptomi na Terluinovim dimenzijama razvijaju u kontekstu suočavanja sa stresorima (Terluin at al., 2004), da ovo istraživanje te strategije nije ispitivalo, kao i da se efekat afektivnih temperamenata na razvoj simptoma depresivnosti menja u zavisnosti od intenziteta stresa (Gonda et al., 2020). 


\section{Reference}

Akiskal, H. S., \& Akiskal, K. K. (2007). In search of Aristotle: Temperament, human nature, melancholia, creativity and eminence. Journal of Affective Disorders, 100(1-3), $1-6$.

Akiskal, H. S., Akiskal, K. K., Haykal, R. F., Manning, J. S., \& Connor, P. D. (2005a). TEMPS-A: progress towards validation of a self-rated clinical version of the Temperament Evaluation of the Memphis, Pisa, Paris, and San Diego Autoquestionnaire. Journal of Affective Disorders, 85(1-2), 3-16.

Akiskal, H. S., Mendlowicz, M. V., Jean-Louis, G., Rapaport, M. H., Kelsoe, J. R., Gillin, J. C., \& Smith, T. L. (2005b). TEMPS-A: validation of a short version of a self-rated instrument designed to measure variations in temperament. Journal of Affective Disorders, 85(1-2), 45-52.

Andress, G., Neilson, M., Hunt, C., Stewart, G. and Kiloh, L. G. (1990). Diagnosis, personality and the long-term outcome of depression. British Journal of Psychiatry, 157(1), 13-18.

Biederman, J., Rosenbaum, J. F., Hirshfeld, D. R., Faraone, S. V., Bldue, E. A., Gersten, M., . . Reznick, J. (1990). Psychiatric Correlates of Behavioral Inhibition in Young Children of Parents With and Without Psychiatric Disorders. Archives of General Psychiatry, 47(1), 21-26.

Clark, L. A., \& Watson, D. (1991a). General affective dispositions in physical and psychological health. In C.R. Snyder, \& Forsyth, D. R. (Eds.), Handbook of Social and Clinical Psychology: the Health Perspective (pp. 221-245). Pergamon, New York.

Clark, L. A. \& Watson, D. (1991b). Tripartite model of anxiety and depression: psychometric evidence and taxonomic implications. Journal of Abnormal Psychology, 100(3), 316-336.

Clark, L. A., Watson, D., \& Mineka, S. (1994). Temperament, personality, and the mood and anxiety disorders. Journal of Abnormal Psychology, 103(1), 103-116.

Dembińska-Krajewska, D., \& Rybakowski, J. (2014). The Temperament Evaluation of Memphis, Pisa and San Diego Autoquestionnaire (TEMPA-a) - an important tool to study affective temperaments. Psychiatria Polska, 48(2), 261-67.

Džamonja-Ignjatović, T., \& Milanović, M. (2012). Psihobiološki model ličnosti - kritička analiza. Godišnjak Fakulteta političkih nauka, 6(7), 199-213.

Figueira, M. L., Caeiro, L., Ferro, A., Cordeiro, R., Duarte, P. M., Akiskal, H. S., \& Akiskal, K. K. (2010). Temperament in Portuguese university students as measured by TEMPS-A: implications for professional choice. Journal of Affective Disorders, 123(1-3), 30-35.

Gonda, X., Eszlári, N., Sutori, S., Aspan, N., Rihmer, Z., Juhasz, G., \& Bagdy, G. (2020). Nature and Nurture: Effects of Affective Temperaments on Depressive Symptoms Are Markedly Modified by Stress Exposure. Frontiers in Psychiatry, 11, 599.

Goodyear, I. M., Ashby, L., Altham, P. M. E., Vize, C., \& Cooper, P. J. (1993). Temperament and major depression in 11 to 16 year olds. Journal of Child Psychology and Psychiatry, 34(8), 1409-1423. 
Hinić, D., Akiskal, S. H., Akiskal, K. K., Jović, J., \& Ristić, D. I. (2013). Validation of the Temps-A in university student population in Serbia. Journal of Affective Disorders, 149(1-3), 146-151.

Jelić, D., Popov, B., \& Sretković, T. (2014). Psihometrijske karakteristike PHCC upitnika ispitne anksioznosti. Primenjena psihologija, 7(1), 23-44.

Kagan, J. (2014). Temperament. In CEECD, Encyclopedia on early childhood development. Retrieved from http://www.child-encyclopedia.com/sites/default/files/ textes-experts/en/892/temperament.pdf

Karam, E. G., Salamoun, M. M., Yeretzian, J. S., Mneimneh, Z. N., Karam, A. N., Fayyad, J., . . Akiskal, H. S. (2010). The role of anxious and hyperthymic temperaments in mental disorders: a national epidemiologic study. World Psychiatry, 9(2), 103-110.

Kawamura, Y., Akiyama, T., Shimada, T., Minato, T., Umekage, T., \& Noda, Y. (2010). Six-year stability of affective temperaments as measured by TEMPS-A. Psychopathology, 43(4), 240-47.

Lazary, J., Gonda, X., Benko, A., Gacser, M., \& Bagdy, G. (2009). Association of depressive phenotype with affective family history is mediated by affective temperaments. Psychiatry Research, 168(2), 145-152.

Maremmani, I., Dell'Osso, L., Rovai, L., Arduino, G., Montagnari, A., Abbenante, D., . . . Akiskal, H. S. (2011). Discriminant and convergent validity of TEMPS-A[P] correlation with MMPI and the emotional-affective state following a stressful situation. Journal of Affective Disorders, 129 (1-3), 27-33.

Marić, J. (2005). Klinička psihijatrija. Beograd: Megraf.

Morvan, Y., Tibaoui, F., Chantal Bourdel, M., Loo, H., Akiskal, K. K., Akiskal, H. S., \& Krebs, M.O. (2011). Confirmation of the factorial structure of temperamental autoquestionnaire TEMPS-A in non-clinical young adults and relation to current state of anxiety, depression and to schizotypal traits. Journal of Affective Disorders, 131(1-3), 37-44.

Preti, A., Vellante, M., Gabbrielli, M., Lai, V., Muratore, T., Pintus, E., Pintus, M., Sanna, S., Scanu S., Tronci, D., Corrias, I., Petretto D. R., \& Scanu, M. G. (2013). Confirmatory factor analysis and measurement invariance by gender, age and levels of psychological distress of the short TEMPS-A. Journal of Affective Disorders, 151(3), 995-1002.

Ratković, D. (2017). Uticaj temperamenta na nastanak i razvoj zavisnosti od opijata. (Neobjavljena doktorska teza). Medicinski fakultet, Novi Sad.

Rende, R. D. (1993). Longitudinal relations between temperament traits and behavioral syndromes in middle childhood. Journal of American Academy of Child and Adolescent Psychiatry, 32 (2), 287-290.

Ristić-Ignjatović, D., Hinić, D., Bessonov, D., Akiskal, H. S., Akisakl, K. K., \& Ristić, B. (2014). Towards validation of the short TEMPS-A in non-clinical adult population in Serbia. Journal of Affective Disorders, 164(1-3), 43-49.

Rovai, L., Leonardi, A., Bacciardi, S., Giovanni, A., Maremmani, I., Rugani, F., . . Akiskal, H. S. (2013a). Discriminant and convergent validity of TEMPS-A[P]. Correlation with Occupational Personality Questionnaire (OPQ32) during a stressful situation. Journal of Affective Disorders, 146 (1), 142-145. 
Rovai, L., Maremmani, A., Rugani, F., Bacciardi, S., Pacini, M., \& Dell'Osso, L. (2013b). Do Akiskal \& Mallya's affective temperaments belong to the domain of pathology or to that of normality? European Review for Medical and Pharmacological Sciences, 17(15), 2065-2079.

Rózsa, S., Rihmer, Z., Gonda, X., Szili, I., Rihmer, A., Kő, N., Németh, A., Pestality, P., Bagdy, G., Alhassoon, O., Akiskal, K. K., \& Akiskal, H. S. (2008). A study of affective temperaments in Hungary: internal consistency and concurrent validity of the TEMPS-A against the TCI and NEO-PI-R. Journal of Affective Disorders, 106(1-2), $45-53$.

Signoretta, S., Maremmani, I., Liguori, A., Perugi, G., \& Akiskal, H. (2005). Affective temperament traits measured by TEMPS-I and emotional-behavioral problems in clinically-well children, adolescents, and young adults. Journal of Affective Disorders, 85(1-2), 169-180.

Strelau, J., \& Zawadzki, B. (2011). Trauma and Temperament as Predictors of Intensity of Posttraumatic Stress Disorder Symptoms After Disaster. European Psychologist, 10, 124-135.

Terluin, B., van Marwijk, H. W., Ader, H. J., de Vet, H. C., Penninx, B. W., Hermens, M. L., . . . Stalman, W. A. (2006). The Four-Dimensional Symptom Questionnaire (4DSQ): a validation study of a multidimensional self-report questionnaire to assess distress, depression, anxiety and somatization. BMC psychiatry, 6,34.

Terluin, B., Van Rhenen, W., Schaufeli, W. B., \& De Haan, M. (2004). The Four-Dimensional Symptom Questionnaire (4DSQ): measuring distress and other mental health problems in a working population. Work and Stress, 18(3), 187-207.

Tubman, J. G., \& Windle, M. (1995). Continuity of diffcult temperament in adolescence: relations with depression, life events, family support, and substance use across a oneyear period. Journal of Youth and Adolescence, 24, 133-153.

Vázquez, G., Tondo, L., Mazzarini, L., \& Gonda, X. (2012). Affective temperaments in general population: A review and combined analysis from national studies. Journal of Affective Disorders, 139(1), 18-22.

Windle, M. (1991). The difficult temperament in adolescence: Associations with substance use, family support, and problem behaviors. Journal of Clinical Psychology, 47(2), 310-315.

Walsh, M. A., Brown, L. H., Barrantes-Vidal, N., \& Kwapil, T. R. (2013). The expression of affective temperaments in daily life. Journal of Affective Disorders, 145(2), $179-186$.

Walsh, M., Royal, A. M., Barrantes-Vidal, N., \& Kwapil, T. (2012). The association of affective temperaments with impairment and psychopathology in a young adult sample. Journal of Affective Disorders, 141(2-3), 373-381.

Watson, D.,\& Clark, L. A. (1984). Negative affectivity: the disposition to experience aversive emotional states. Psychological Bulletin, 96(3), 465-490.

Watson, D., \& Clark, L. A. (1995). Depression and the melancholic temperament. European Journal of Personality, 9(5), 351-366.

Windle, M. (1991). The diffcult temperament in adolescence: associations with substance use, family support, and problem behaviors. Journal of Clinical Psychology, 47(2), $310-315$. 
Dušan Vlajić ${ }^{3}$

Department of Psychology,

Faculty of Philosophy, University of Niš

Niš, Serbia

\title{
Danica Trajković
}

Niš, Serbia

\section{THE RELATION OF THE AFFECTIVE TEMPERAMENT WITH THE MENTAL HEALTH DIMENSIONS}

\begin{abstract}
This paper examines the relationship between affective temperaments (depressive, cyclothymic, hyperthymic, irritable, anxious-cognitive, and anxious-somatic) and symptoms of Terluin's four dimensions of mental health (Distress, Depression, Anxiety, and Somatization). The sample is convenient, consisted of 190 people under the age of 35. The instruments used in the research are the following: the Serbian version of the TEMPS-A scale, which assess affective temperaments, and The Four-Dimensional Symptom Questionnaire (4DSQ). Results show that depressive and cyclothymic temperament are significant predictors of all Terluin's dimensions. In addition, Anxiety can be significantly predicted based on hyperthymic, anxious-cognitive, and anxious-somatic temperament, and Somatization based on anxious-somatic temperament. Affective temperaments have a positive contribution to all regression models, except for hyperthymic temperament, which has a negative one. The main conclusion of the research is that in people with depressive, anxiety and somatic temperament characteristics, in stressful situations those characteristics can be intensified. Also, hyperthymic temperament, which is characterized by the largest number of desirable traits, could show a potential protective role in relation to the development of symptoms on Terluin's dimensions.
\end{abstract}

Key words: affective temperament, dimensions of mental health, distress

Primljeno: 30.04 .2020 .

Primljena korekcija: 05.09.2020.

Prihvaćeno za objavljivanje: 08.09.2020.

\footnotetext{
${ }^{3}$ dusan.vlajic@filfak.ni.ac.rs
} 